\title{
Response of circulating leptin to Ramadan daytime fasting: a circadian study
}

\author{
André Bogdan ${ }^{1}$, Belal Bouchareb ${ }^{2}$ and Yvan Touitou ${ }^{1 *}$ \\ ${ }^{1}$ Laboratoire de Biochimie, Faculté de Médecine Pitié-Salpétrière 91 boulevard de l'Hôpital, 75013, Paris, France \\ ${ }^{2}$ Laboratoire d'Hormonologie, Hôpital Militaire Universitaire Oran, Algeria
}

(Received 14 April 2004 - Revised 12 October 2004 - Accepted 19 November 2004)

\begin{abstract}
Although the effects of short-term fasting on serum leptin concentrations are known, those resulting from long-lasting modifications of food intake schedule, as during the month of Ramadan, have not yet been extensively studied. Therefore, serum concentrations of leptin were measured around the clock at 4-hourly intervals before the beginning of Ramadan and on the twenty-third day of Ramadan daytime fasting in ten male subjects keeping the same usual activity pattern and general synchronisation in both situations. Time series were analysed with repeated measures ANOVA and Cosinor. No significant changes in amplitude or $24 \mathrm{~h}$ mean concentration were seen, but significant shifts of $5 \mathrm{~h} 30 \mathrm{~min}$ in peak and trough serum leptin levels were found on the twenty-third day of Ramadan.
\end{abstract}

Rhythms: Leptin: Fasting: Ramadan

Leptin, the protein product of the obese gene, is known to play an important role in the regulation of body weight (Zhang et al. 1994), and its circadian rhythm has been shown in short-term studies to be entrained to meal timing (Schoeller et al. 1997). Besides its role in body weight regulation, leptin has also been shown to be an hormonal signal at central nervous system level and a regulator of neuroendocrine function (reviewed in Harvey \& Ashford, 2003).

One of the most important rules of Islam is that any healthy adult Muslim must refrain from eating, drinking, smoking and sexual relations from sunrise to sunset during the month of Ramadan, the ninth month of the Muslim calendar. Since this is a lunar calendar, the timing of this month of fasting changes each year, and the duration of restricted food and beverage intake can vary between 12 and $16 \mathrm{~h}$. Intake is restricted to the night hours within a short span of time, which thus delays sleep and reduces its duration.

Environmental factors such as the timing of the rest-activity cycle (Apfelbaum et al. 1969) and meals (Zigmond et al. 1969; Halberg, 1974; Nelson et al. 1975) play a part in the synchronisation of individuals to the $24 \mathrm{~h}$ day (and are accordingly known as synchronisers). They modulate or modify one or several of the parameters characterising the circadian rhythm of a biological variable (Reinberg, 1991; Touitou \& Haus, 1994). It was previously shown that changes in the circadian rhythms of biological variables, including various hormones, occur during Ramadan (Iraki et al. 1997a,b; Bogdan et al. 2001). Although the effects of short-term fasting upon leptin have already been described (Boden et al. 1996), those of a long-lasting inversion of the food intake schedule have not yet been documented. The purpose of the present study was to assess how Ramadaninduced modifications of food intake and sleep schedule would modify the pattern of serum leptin concentration because of the possible consequences for public health of Muslim members of the population.

\section{Subjects and methods}

Subjects

All the subjects underwent routine clinical and laboratory examinations, with no abnormal findings. None had any acute or chronic somatic or psychiatric disorder, or any infectious or endocrine disease, and none had taken a transmeridian flight within 2 months of the study. No subject took any drug or received any medical treatment immediately before or during this study. Volunteers meeting these inclusion criteria participated in the study (Toitou et al. 2004). The protocol was approved by the Ethics Committee of the Faculty of Medicine of Oran, Algeria. Ten healthy, non-smoking, male volunteers (medical doctors in the hospital where the study was undertaken) were included in the study and gave their written informed consent. Their ages ranged from 32 to 40 years (mean 34, SD 3.7).

\section{Experimental procedure}

The volunteers were studied twice during a $24 \mathrm{~h}$ span: 1 week before Ramadan (control: end of December) and on the twentythird day of Ramadan (Ramadan: end of January). On both test days, leptin was measured from each of six blood samples drawn from the antecubital vein through an indwelling catheter at the following times: 08.15 hours, 12.15 hours, 16.15 hours, 20.15 hours, 00.15 hours and 04.15 hours. Blood sampled during the rest time was drawn under illumination with dim red light ( $<30$ lux). Samples were allowed to clot, and the serum was centrifuged, divided into aliquots and stored at $-20^{\circ} \mathrm{C}$ until analysed. 
Before Ramadan started, the subjects were synchronised to nocturnal rest from 00.00 hours \pm 01.00 hours to 07.00 hours \pm 01.00 hours and to diurnal activity. On test days, they were awakened at 04.15 hours to have their blood drawn. Physical activity did not differ qualitatively or quantitatively during Ramadan compared with the control day (subjects having the same tasks and working hours before and during Ramadan). During Ramadan, except for the test day, the subjects slept without interruption from 02.00 hours to 08.00 hours. Their average sleep time was thus $1 \mathrm{~h}$ shorter during Ramadan than it had been during the control period. Since the purpose of the study was to look for changes related to Ramadan, the lighting conditions (uncontrolled) were those habitual for the season and the activity of the subjects who remained indoors during the test days (with the same domestic intensity for all). All meals were quantitatively and qualitatively standardised by a nutritionist and were eaten at fixed hours that fitted with the subjects' usual schedules and Ramadan customs.

Meal timing and composition before Ramadan were as follows: 08.00 hours: bread, butter, coffee and milk (approximately $1674 \mathrm{~kJ}(400 \mathrm{kcal})$ ); 12.00 hours: meat, vegetables, bread and fruit (around $5442 \mathrm{~kJ}(1300 \mathrm{kcal}))$; 19.00 hours: soup, noodles and chicken (approximately $4186 \mathrm{~kJ}(1000 \mathrm{kcal}))$. During Ramadan, meal timing and composition, as determined by the local custom, were: 19.00 hours: milk, dates, soup, meat, vegetables, bread, fruit, coffee and pastry (approximately $8373 \mathrm{~kJ}$ $(2000 \mathrm{kcal})$ ); 01.00 hours: semolina, milk, fruit and pastry (in the region of $2512 \mathrm{~kJ}(600 \mathrm{kcal}))$.

\section{Statistical analysis}

Time series were submitted to analysis of variance (ANOVA for repeated measures) with Statview 5.0 software (SAS Institute Inc., Cary, NC, USA) to test the time-related variations (effect of time on both experimental days), the influence of Ramadan upon the $24 \mathrm{~h}$ mean concentrations (Ramadan $v$. control) and the possible interaction between Ramadan and the time-related variations (experimental day and time interaction). Paired comparisons of blood concentrations and of peak times or $50 \%$ increase times were made using Wilcoxon's test. In addition, time series were analysed with Cosinor analysis, which uses a computer program and a least-squares method to find the best-fitting cosine function approximating all the data. This allows an estimation of the parameters characterising the rhythm together with their $95 \%$ confidence limits. These parameters are: the period, equal here to $24 \mathrm{~h}$ since it corresponds to the average periodicity of synchronisation of the subjects by the activity/rest cycle; the acrophase, which is the peak time of the cosine function used to approximate the rhythm; the amplitude equal to half of the total rhythmic variability per $24 \mathrm{~h}$; the middle estimated statistic of rhythm with its SEM. This method validates a rhythm when its amplitude differs from zero with $P<0.05$; the percentage of rhythm represents the percentage of the total variability explained by the model. Bingham's test was used to look for significant differences in Cosinor parameters between the control day and the Ramadan day.

\section{Measurement of serum leptin}

Serum leptin was measured directly by a specific RIA (Human Leptin RIA kit; Linco Research Inc., St Charles, MO, USA); the analytical sensitivity was $0.5 \mu \mathrm{g} / \mathrm{l}$. The interassay $\mathrm{CV}$ was
$1.9 \%$ at $2.9 \mu \mathrm{g} / \mathrm{l}$ and $7.1 \%$ at $18.0 \mu \mathrm{g} / \mathrm{l}$. The intra-assay coefficient was $8.0 \%$.

\section{Results}

Fig. 1 shows the patterns of serum leptin concentrations on the control day and on the twenty-third day of Ramadan daytime fasting. Clearly, the restriction of food and beverage intake to the night hours resulted in a time shift of leptin serum concentration, as assessed by Wilcoxon's test for peak times $(P=0.0431)$ and times of $50 \%$ increase $(P=0.0117)$. During Ramadan, although an obvious trend for decreased minimum concentrations was visible, it was not found to be statistically significant, while concentrations at 20.00 hours were significantly lower $(P=0.0251)$ than on the control day. No significant difference was seen for $24 \mathrm{~h}$ mean concentrations.

The ANOVA for repeated measures found significant timerelated variations in leptin serum concentration ( $F$ 15.468, $P<0.0001)$. The significant interaction between experimental day (Ramadan day $v$. control day) and the time-related variations ( $F$ 9.382, $P<0.0001$ ) further assessed the time-shift observed in Fig. 1. Again, no significant difference in mean concentration was found ( $F$ 0.262, $P=0.6247)$ when comparing the Ramadan and control days.

Cosinor analysis (Table 1) found a significant circadian rhythm on both the control day and the twenty-third day of Ramadan, with a good fitting of the cosine model (percentage rhythm 78 and 87, respectively). Again, Bingham's test applied to the model parameters found a significant shift (approximately $5 \mathrm{~h}$ $30 \mathrm{~min}$ ) in the acrophase of the serum leptin concentration when

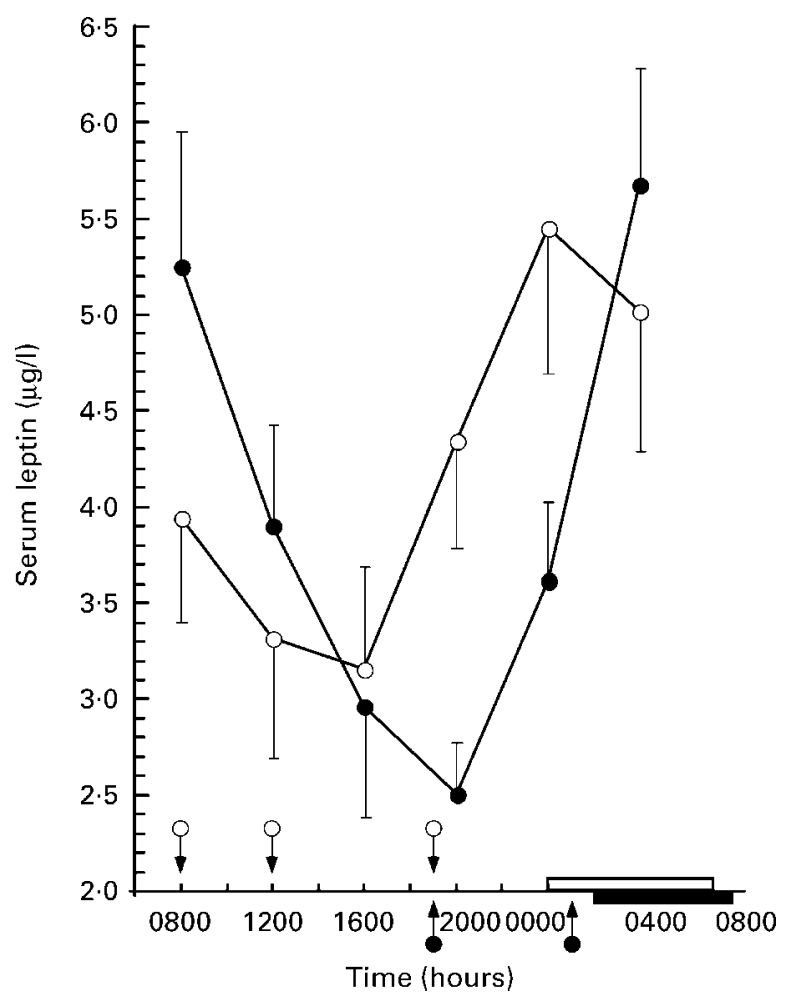

Fig. 1. Circadian pattern of serum leptin concentrations in ten healthy male volunteers before and on the twenty-third day of Ramadan daytime fasting. Each point represents the mean and SEM of ten subjects. Values before

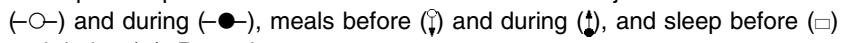
and during (-), Ramadan. 
Table 1. Cosinor summary of serum leptin concentration circadian rhythms on the control day (before) and on the twenty-third day (during) of Ramadan daytime fasting

\begin{tabular}{|c|c|c|c|c|c|c|c|c|}
\hline & \multicolumn{8}{|c|}{ Cosinor summary } \\
\hline & \multirow{2}{*}{$\begin{array}{l}\text { Percentage } \\
\text { of rhythm }\end{array}$} & \multirow[b]{2}{*}{$P$} & \multicolumn{2}{|c|}{ MESOR $(\mu \mathrm{g} / \mathrm{l})$} & \multicolumn{2}{|c|}{ Amplitude $(\mu \mathrm{g} / \mathrm{l})$} & \multicolumn{2}{|c|}{ Acrophase (h.min) } \\
\hline & & & & SEM & & $95 \% \mathrm{Cl}$ & & $95 \% \mathrm{Cl}$ \\
\hline Before & 78 & 0.024 & $4 \cdot 20$ & 0.56 & $1 \cdot 17$ & $0.4-2.0$ & $01 \cdot 24$ & $00.20-03.48$ \\
\hline During & 87 & 0.005 & 4.03 & 0.45 & 1.65 & $0.9-2.3$ & $06 \cdot 08$ & $05.04-06.56$ \\
\hline \multicolumn{9}{|c|}{ Bingham's test ${ }^{*}$} \\
\hline & & & & df & $F$ & $P$ & & \\
\hline & & MESOR & & 1,14 & 0.62 & 0.8070 & & \\
\hline & & Amplitude & & 1,14 & 4.5187 & 0.0518 & & \\
\hline & & Acrophase & & 1,14 & $15 \cdot 2707$ & 0.0016 & & \\
\hline
\end{tabular}

MESOR, middle estimated statistic of rhythm.

*Bingham's test was used to validate possible differences in MESOR, amplitudes and acrophases.

comparing the Ramadan day with the control day ( $F$ 15.2707, $P=0 \cdot 0016)$. Although Bingham's test found no difference in middle estimated statistics of rythm, the trend for a difference in amplitudes was again suspected but not validated ( $F$ 4.5187, $P=0 \cdot 0518)$.

\section{Discussion}

Ramadan is the month during which Muslims must refrain from eating and drinking from sunrise until sunset while maintaining their usual social and occupational activities. These long-lasting modifications have been shown to result in a phase delay of many biological rhythms (Al-Hadramy et al. 1987; Bensouda et al. 1991; Aadil-Benchekroun, 1993; Haouari-Ourerro et al. 1994). We recently reported the alteration of the circadian patterns of biological variables both related (Iraki et al. 1997b) and not related (Bogdan et al. 2001) to nutrition, which reinforces the importance to the debate of mealtimes as a rhythm synchroniser in man. The increase in percentage of rhythm and the lower $P$ value reported here during Ramadan when compared with the control day indeed support the hypothesis of a synchronisation of the present subjects by the Ramadan regimen.

The circadian rhythm of serum leptin has previously been described (Sinha et al. 1996; Saad et al. 1998; Simon et al. 1998; Zhao et al. 2002a), as has its relation to meal timing (Schoeller et al. 1997; Dallongeville et al. 1998), but although the effects of acute or short-term fasting in human subjects have been examined, the consequences of prolonged intermittent fasting on serum leptin rhythm have not, to our knowledge, yet been evaluated, thus prompting this study. Since the purpose of our investigation was to consider the modifications in serum leptin concentration in human subjects observing the rule of Ramadan, we did not attempt to change the subjects' environmental conditions or behavioural customs (including their eating habits). Light exposure characteristics were the same during the control and Ramadan periods except for their duration ( $1 \mathrm{~h}$ longer during Ramadan). The pattern of serum leptin concentration before Ramadan (control day) observed in the present study is in good agreement with those previously reported (Sinha et al. 1996; Schoeller et al. 1997).
On the twenty-third day of Ramadan daytime fasting, the present study shows obvious modifications in the rhythmic pattern even though the sleep schedule of the subjects studied here was much less shortened and delayed than that in another study of Ramadan-induced changes in subjects who stayed awake until dawn (Al-Hadramy et al. 1987). Although both ANOVA and Cosinor disclosed no changes in the $24 \mathrm{~h}$ mean concentrations of serum leptin during Ramadan daytime fasting, a significant shift (approximately $5 \mathrm{~h}$ delay) in the rhythm was observed. Even though a meal was given at 19.00 hours in both situations, it has to be noted that the concentrations of serum leptin at this time point were significantly lower on the Ramadan day than the control day, and that the increase in serum concentration therefore preceded food intake in the control situation, whereas it followed it during Ramadan.

Other reports (Schoeller et al. 1997; Eliman \& Marcus, 2002) are in agreement with our data despite differences in protocol design. However, the present study is the only one to report leptin rhythm alterations by prolonged $(23 \mathrm{~d})$ modifications of meal timing ( 01.00 hours and 20.00 hours only) in subjects maintaining their usual activity and energy expenditure. Whereas others (Eliman \& Marcus, 2002) have found that an evening breaking-fast meal induced a higher leptin response, this was not the case in the present study since the apparent increase in amplitude of leptin circadian rhythm was not found to be significant, possibly because the duration of daytime fasting was much longer. Finally, these differences may also be related to differences in geographic and ethnic origin and/or dietary habits, as already reported for leptin (Nicklas et al. 1997), cortisol (Zhao et al. 2003a,b), melatonin (Zhao et al. 2002b) and other biological measurements (Wetterberg et al. 1979, 1986; Kawasaki et al. 1980; Woo et al. 1988, 1989; Leung et al. 1993).

There is growing evidence that leptin functions as more than just a satiety signal in the central nervous system: it is also an important hormonal signal in the developing central nervous system (reviewed in Harvey \& Ashford, 2003). For all these reasons, and because the rule of Ramadan - 1 month of daytime fasting every year - is repeatedly followed from puberty to old age by a large majority of the Muslim population, the possible 
consequences of this long-lasting modification of food intake schedule on public health need to be documented.

\section{References}

Aadil-Benchekroun N (1993) Influence du jeûne du Ramadan sur la pharmacocinétique de la théophylline et le cycle du cortisol (Influence of Ramadan fasting on the pharmacokinetic of theophylline and on the cycle of cortisol). Doctoral thesis, Université Claude Bernard, Lyon, France.

Al-Hadramy MS, Zawawi TH \& Abdelwahab SM (1987) Altered cortisol levels in relation to Ramadan. Eur J Clin Nutr 42, 359-362.

Apfelbaum M, Reinberg A, Nillus P \& Halberg F (1969) Rythmes circadiens de l'alternance veille/sommeil pendant l'isolement. Presse Méd $77,879-882$.

Bensouda JD, Ouazzani W, Lachkar A, Harniani A \& Belkhadir J (1982) Variations du cycle du cortisol sous l'influence du jeûne au cours du mois de Ramadan. Symposium International 22-23 Octobre 1991, Rabat-Maroc. In Bases Actuelles de l'Exploration Hormonale, p. 82. Paris, France: SEPE/FRH.

Boden G, Chen X, Mozzoli M \& Ryan I (1996) Effect of fasting on serum leptin in normal human subjects. J Clin Endocrinol Metab 81, 3419-3423.

Bogdan A, Bouchareb B \& Touitou Y (2001) Ramadan alters endocrine and neuroendocrine circadian patterns. Meal-time as a synchronizer in humans? Life Sci 68, 1607-1615.

Dallongeville J, Hecquet B, Lebel P, Edmé J-L, Le Fur C, Fruchart J-C, Auwerx J \& Romon M (1998) Short term response of circulating leptin to feeding and fasting in man: influence of circadian cycle. Int J Obes 22, 728-733.

Eliman A \& Marcus C (2002) Meal timing, fasting and glucocorticoids interplay in serum leptin concentrations and diurnal profile. Eur $J$ Endocrinol 147, 181-188.

Halberg F (1974) Protection by timing treatment according to bodily rhythms. An analogy to protection by scrubbing before surgery. Chronobiologia 1, Suppl. 1, 27-72.

Haouari-Ourerro F, Haouari M, Aouidet A, Sfaxi A, Hedhili A \& Nagati K (1994) Ramadan et rythmes circadiens des taux sériques de la bilirubine des enzymes hépatiques et des oligo-élements $\left(\mathrm{Mg}^{2+}, \mathrm{Cu}^{2+}\right.$, $\mathrm{Zn}^{2+}$ ). Ramadan and circadian rhythms of the serum concentrations of bilirubine, hepatic enzymes and oligo-elements. In Proc. of $l^{\text {er }}$ Congrès International Ramadan et Santé, Casablanca, Maroc (abstract).

Harvey J \& Ashford MLJ (2003) Leptin in the CNS: much more than a satiety signal. Neuropharmacology 44, 845-854.

Iraki L, Abkari A, Vallot T, Amrani N, Khlifa RH, Jellouli K \& Hakkou F (1997a) Effet du jeûne du Ramadan sur le pH intragastrique enregistré sur 24 heures chez le sujet sain. Effect of Ramadan fasting on the intragastric pH recorded 24 hours in healthy subjects. Gastroentérol Clin Biol 21, 813-819.

Iraki L, Bogdan A, Hakkou F, Abkari A \& Touitou Y (1997b) Ramadan diet restrictions modify the circadian time structure in humans. A study on plasma gastrin, insulin, glucose and calcium and on gastric $\mathrm{pH} . J$ Clin Endocrinol Metab 82, 1261-1273.

Kawasaki T, Ueno M, Uezono K, Matsuoka M, Omae T, Halberg F, Wendt H, Taggett-Anderson MA \& Haus E (1980) Differences and similarities among circadian characteristics of plasma renin activity in healthy young women in Japan and the United States. Am J Med 68, 91-96.

Leung SY, Ng TH, Yuen ST, Lauder IJ \& Ho FC (1993) Patterns of cerebral atherosclerosis in Hong Kong Chinese. Severity in intracranial and extracranial vessels. Stroke 24, 779-786.
Nelson W, Scheving LE \& Halberg F (1975) Circadian rhythms in mice fed a single daily meal and different stages of lighting regimen. $J$ Nutr 105, 171-184.

Nicklas BJ, Toth MJ, Goldberg AP \& Poehlman ET (1997) Racial differences in plasma leptin concentrations in obese postmenopausal women. $J$ Clin Endocrinol Metab 82, 315-317.

Reinberg A (1991) Chronobiologie et Chronothérapeutique; Heure Optimale d'Administration des Médicaments. Paris: Flammarion MédecineSciences.

Saad MF, Riad-Gabriel MG, Khan A, Sharma A, Michael R, Jinagouda SJ, Boyadjian R \& Steil GM (1998) Diurnal and ultradian rhythmicity of plasma leptin: effect of gender and adiposity. J Clin Endocrinol Metab 83, 453-459.

Schoeller DA, Cella LK, Sinha MK \& Caro JF (1997) Entrainment of the diurnal rhythm of plasma leptin to meal timing. J Clin Invest 100, $1882-1887$.

Simon C, Gronfier C, Schlienger JL \& Brandenberger G (1998) Circadian and ultradian variations of leptin in normal man under continuous enteral nutrition: relationship to sleep and body temperature. J Clin Endocrinol Metab 83, 1893-1899.

Sinha MK, Ohannesian JP, Heiman ML, Kriauciunas A, Stephens TW, Magosin S, Marco C \& Caro JF (1996) Nocturnal rise of leptin in lean, obese, and non-insulin-dependent diabetes mellitus subjects. $J$ Clin Invest 97, 1344-1347.

Touitou Y \& Haus E (1994) Biologic Rhythms in Clinical and Laboratory Medicine. Berlin: Springer Verlag.

Touitou Y, Portaluppi F, Smolensky M \& Rensing L (2004) Ethical principles and standards for the conduct of human and animal biological rhythm research. Chronobiol Int 21, 161-170.

Wetterberg L, Halberg F, Halberg E, Haus E, Kawasaki T, Ueno M, Uezono K, Cornelissen G, Matsuoka M \& Omae T (1986) Circadian characteristics of urinary melatonin from clinically healthy young women at different civilization disease risks. Acta Med Scand 220 , $1-81$.

Wetterberg L, Halberg F, Tarquini B, et al. (1979) Circadian variation in urinary melatonin in clinically healthy women in Japan and the United States of America. Experientia 35, 416-419.

Woo J, Ho SC, Donnan S \& Swaminathan R (1988) Nutritional correlates of blood pressure in elderly Chinese. J Hum Hypertens 1, 287-291.

Woo J, Swaminathan R, Pang CR, MacDonald D, Mak YT, Ho SC \& Lau E (1989) Some biochemical indices of bone turnover in elderly Chinese. J Med 20, 229-239.

Zhang Y, Proenca R, Maffei M, Barone M, Leopold L \& Friedman JM (1994) Positional cloning of the mouse obese gene and its homologue. Nature 372, 425-432.

Zhao ZY, Fu YR, Li XH, Li YY, Bogdan A \& Touitou Y (2002a) Agerelated modifications of circadian rhythm of serum leptin in healthy men. Gerontology 48, 309-314.

Zhao ZY, Xie Y, Fu YR, Bogdan A \& Touitou Y (2002b) Aging and the circadian rhythm of melatonin: a cross-sectional study of Chinese subjects 30-110 yr of age. Chronobiol Int 19, 1171-1182.

Zhao ZY, Xie Y, Fu YR, Bogdan A \& Touitou Y (2003a) Circadian rhythm characteristics of serum cortisol and dehydroepiandrosterone sulfate in healthy Chinese men aged 30 to 60 years. A cross-sectional study. Steroids 68, 133-138.

Zhao ZY, Xie Y, Fu YR, Bogdan A \& Touitou Y (2003b) Cortisol secretion in the elderly. Influence of age, sex and cardiovascular disease in a Chinese population. Steroids 68, 551-555.

Zigmond MJ, Shoemaker WJ, Larin F \& Wurtman RJ (1969) Hepatic tyrosine transaminase rhythm: interaction of environmental lighting, food consumption and dietary protein content. J Nutr 98, $71-75$. 